The goal of the event was to put a name and face to primary care research; to provide important stories to go along with the medical evidence for primary care. Policy makers like stories, and primary care research has not been effective at bringing these stories to our policy makers. The patient-primary care provider dyads agreed with the need for improved research policy and advocacy for primary care and patient-centered research. This combination of needs prompted the group to call for a series of patient engaged programs for long-term implementation within NAPCRG including: patient leadership within NAPCRG, broader patient involvement in NAPCRG strategic planning, program development, annual meeting participation, and patient-provider dyad advocacy work with research funders including elected officials, funding agencies, and academic research organizations.

The NAPCRG Patient-Centered Primary Care Policy and Advocacy preconference provided several new lessons. First, patients and their primary care providers are eager to work with each other on topics and areas outside of the individual direct patient care. We heard many stories from the patient/provider dyads about how they might impact their local community health. For instance, one patient and her primary care provider told about their work on identifying and mitigating radon exposure in their small rural lowa farm town. They have now partnered with several researchers at the University of lowa to further this research and disseminate it more widely throughout lowa. Second, patients want to become more involved in the research agenda at NAPCRG. This spring, several participants from the conference will travel to Washington, DC, to share their experiences and needs at the annual Family Medicine Congressional Conference. Their trip will include an advocacy visit to discuss patient-centered primary care outcomes research with their federal legislators. Another patient will be joining the NAPCRG Board strategic planning retreat. Patients and providers want to judge posters at NAPCRG's Annual Meeting and present the "People's Choice Award" to the research with the most appeal to patients and primary care providers.

Third, the space where patients and their primary care provider interact is crucial to the translation and implementation of high quality health care. The participants were adamant that the most important research that might help them is research that provides information and tools for conversations, negotiations, and care between the patient and their primary care provider. Efforts that only engage the practice, the specialist, the physician are not adequate. Efforts that only target the patient may not be sufficient. We believe that the dyad is unique structure for enhancing patient-centered outcomes research.
NAPCRG planners started this process hoping to find patients and physicians willing to advocate for primary care research. What we got is a cadre of activated patients and physicians that want to be part of every thing NAPCRG does. NAPCRG members can expect to see more patient engagement in the coming years, resources for patient engagement and participatory research, and patient and primary care provider leadership within NAPCRG. And they might even judge your research for the People's Choice Award. Jack Westfall, MD, MPH

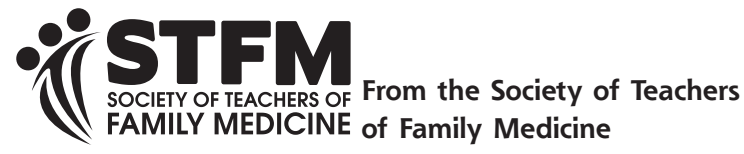

Ann Fam Med 2014;285-286. doi: 10.1370/afm.1658.

\section{TASK FORCE PROVIDES UPDATE ON RESIDENCY ACCREDITATION TOOLKIT PROGRESS}

The STFM Task Force has spent the first half of 2014 developing user-friendly tools, templates, checklists, modules, lectures, and more that residency programs will need to succeed in the Next Accreditation System environment and with the new program requirements. Both become active on July 1, 2014. The new outcomes-based accreditation process will be a drastic change, and residency programs across the country are preparing to transition to a continuous accreditation process.

"As we all continue to evolve our programs into the future of the NAS, we hope that this toolkit serves as a helpful reference for your journey," said Residency Accreditation Task Force Chair Ted Epperly, MD.

The STFM Task Force has focused on these following areas of toolkit development:

- Milestones: information, reporting, mapping, and gap analysis tools

- Milestones assessment and evaluation tools

- Clinical Competency Committee and how to make this hum

- Residents in difficulty and using the CCC

- New FM program requirements and toolkit items to help meet these

- Technology: needs assessment, tools, applications

- Milestones vignettes for program use

- Faculty development: Milestones, direct observation, feedback, entrusted professional activities tools

- Faculty survey and tips on how to use this

- Scholarly activity—what counts and what does not 
- Residency coordinators: tips, glossary, and how to get all of this in ADS and still keep your sanity

- Self-study and PEC tools

- Clinical learning environment review (CLER) visits and tools for success

- Change management and change fatigue modules

- Frequently asked questions (FAQs) related to accreditation

The toolkit will also feature a section of lessons learned that will include best practices from several programs that were involved in the alpha- and betatesting of the Milestones. One of those programs was Mount Carmel Family Medicine Residency in Columbus, Ohio. "We were excited about the Milestones and wanted to learn more about them before the required implementation date," said Tim Graham, MD, director of curriculum and research. "We wanted the opportunity to refine our processes ahead of the rollout." Dr Graham says the beta testing help them identify gaps in their forms and processes and feels that his program is now well prepared for the Next Accreditation System.
After launch of the toolkit, faculty development will be available through both online modules and live events, such as STFM's On The Road workshops. A preconference workshop was recently held at the STFM annual spring conference to unveil the Residency Accreditation Toolkit and update attendees on the task force's progress.

Residency Accreditation Task Force members include: Ted Epperly, MD, Brandy Deffenbacher, $\mathrm{MD}_{i}$ Timothy Graham, MDi Beth Anne Fox, MD Jeff Haney, $\mathrm{MD}_{i}$ Barbara Joyce, $\mathrm{PhD}_{i}$ Tina Kenyon, $\mathrm{ACSW}_{i}$ Richard Neill, MD Judith Pauwels, MDi Erika Ringdahl, MD, Fred Miser, MD, Association of Family Medicine Residency Directors Liaison, and Stan Kozakowski, MD, Residency Program Solutions Liaison.

The toolkit will be hosted on the STFM.org website at http://www.stfm.org/RAToolkit. The timeline for completion of the toolkit is approximately July 2014 , although many items are live on the site now.

Ted Epperly, MD

Residency Accreditation Task Force Chair

\section{Get the Annals of Family Medicine by E-mail}

Make sure you see every new issue

while it's fresh; have the table of

contents sent to you by e-mail for

easy access to articles of interest.

Don't miss important research.

Request the e-mail table of contents at http://lyris.aafp.org/subscribe/annals/.

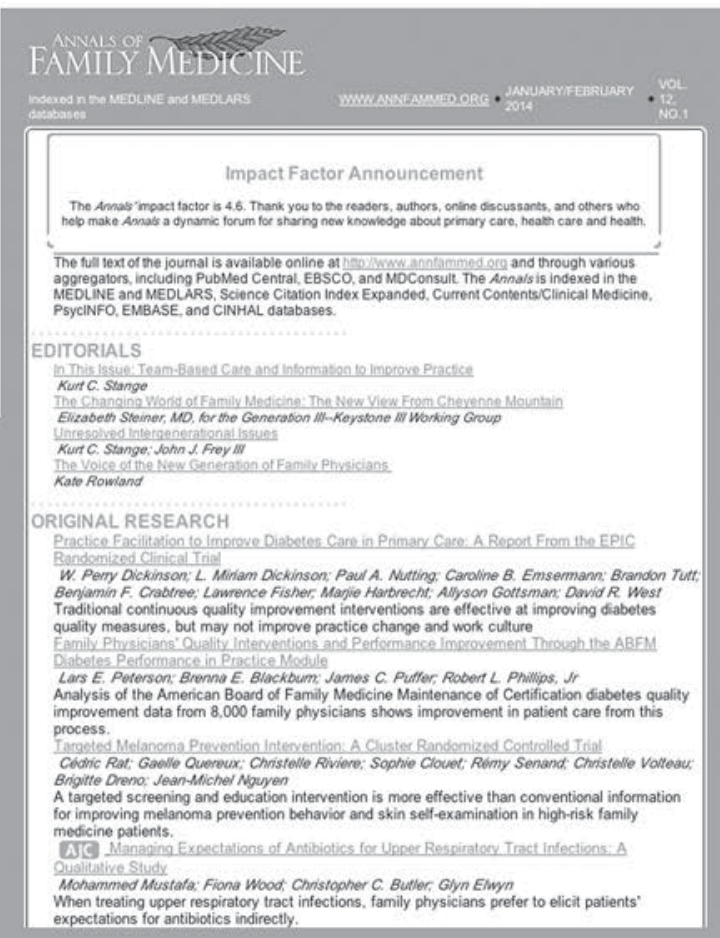

